\title{
Scanning Electron Microscopic and Profilometric Study of Different Sharpening Stones
}

\author{
Roberto Antonio ANDRADE ACEVEDO ${ }^{1}$ \\ Ana Karina Veloso CARDOZO ${ }^{2}$ \\ José Eduardo César SAMPAIO ${ }^{3}$ \\ ${ }^{1}$ Department of Periodontology, School of Dentistry of Araraquara, State University of São Paulo, Araraquara, SP, Brazil \\ ${ }^{2}$ Department of Periodontology, School of Dentistry, Federal University of Bahia, Salvador, BA, Brazil \\ ${ }^{3}$ Department of Diagnosis and Surgery, School of Dentistry of Araraquara, \\ State University of São Paulo, Araraquara, SP, Brazil
}

\begin{abstract}
Scaling and root planing contribute to the recovery of periodontal health. All periodontal instruments loose their fine cutting angle after use. To maintain this angle, correct sharpening is required using specifically designed stones. The characteristics of sharpening stones can be compared to the blade of the instruments and also transported to root surface during instrumentation. Root smoothness is related to the quality of the blade. Therefore, the purpose of this study was to evaluate the characteristics of 9 sharpening stones by scanning electron microscopic and profilometric analyses. Ceramic and Neumar stones were very fine and both may be recommended to maintain the sharpness of the instruments. Arkansas, Thompson and CE stones presented greater roughness with very regular and round particles, and are suitable for maintenance of the cutting angle. In addition, these stones may be indicated for the routine sharpening of the instruments that are partly dull. Oxide Aluminum, Carborundum and JON stones were the coarsest with large irregular particles and may be indicated for initial sharpening of totally dull instruments with completion of sharpening with finer stones.
\end{abstract}

Key Words: scanning electron microscopy, scaling, dental instruments, roughness, sharpening stones.

\section{INTRODUCTION}

Dental biofilm is the main etiologic factor for development of periodontal disease (1). Periodontal therapy is based on not only the mechanical elimination of supra- and subgingival bacterial biofilm but also of calculi, which can harbor microorganisms (2). Scaling and root planing (SRP) are efficient to carry out these objectives and to promote periodontal health (3). SRP should be done with well-sharpened instruments because the smoothness of root surface is directly related to the quality of the instrument cutting edge.

After some strokes, all periodontal instruments loose their fine cutting edge and are less efficient for the removal of bacterial plaque, calculus and contaminated cementum (4-6). A dull curette reduces the tactile sensitivity, increases the pressure required as well as professional fatigue and working time (4). Therefore, the grinding of one or two instrument surfaces with specifically designed stones (natural or artificial, lubricated or not, fine or coarse) is necessary.

It is very important to know sharpening techniques (7), as well as the type of stone that offers more advantages in terms of cutting angle fineness. Coarser stones have large abrasive crystals that cut quickly. Fine stones have small particles and cutting speed is slower, proper for finishing and producing a delicate and smooth cutting edge.

Considering that the characteristics of the cutting edge can be transported to the root surface during SRP procedures $(8,9)$, creating irregularities similar to the sharpening stone employed, the purpose of this study was to evaluate 9 different types of sharpening stones, using scanning electron microscopy (SEM) and

Correspondence: Prof. Dr. José Eduardo César Sampaio, Departamento de Diagnóstico e Cirurgia, Faculdade de Odontologia de Araraquara, UNESP, Rua Humaitá, 1680, 14801-903 Araraquara, SP, Brasil. Tel: +55-16-3301-6369. Fax: +55-16-3301-6369. e-mail: jsampaio@foar.unesp.br 
a profilometer, to determine which type of stone offers the best characteristics of smoothness of the cutting angle of the curettes.

\section{MATERIAL AND METHODS}

Nine unused sharpening stones of different commercial brands were selected: Arkansas SS6A stone (Hu-Friedy, Chicago, IL, USA); FB-24 Fine India stone (Norton, Los Angeles, CA, USA); Aluminum Oxide stone (Newmar, São Paulo, SP, Brazil); Arkansas type stone (CE-MDSS, Burkhardtstr, Hannover, Germany); aluminum oxide, Arkansas type stone (JON, São Paulo, SP, Brazil); Arkansas type stone (Newmar, São Paulo, SP, Brazil); Thompson stone (Thompson Dental Company, Atlanta, GA, USA); Carborundum stone (Carborundum, São Paulo, SP, Brazil); Ceramic stone (S.S. White, Gloucester, UK).

A profilometer (Prazis Rug-03, Buenos Aires, Argentina) was employed to measure the roughness of sharpening stone surfaces by moving a diamond-tracing stylus perpendicularly over the surface. Ten readings on distinct areas were obtained for each type of stone. The profilometric analysis was based on the average roughness $(R a)$ expressed in micrometers.

For SEM analysis, the stones were segmented using a rotary carborundum disc and each segment was coded and mounted on a metal stub with the aid of an uncolored glazing mixed with graphite. The specimens were completely dehydrated in a special dehydration chamber (innertube-pirex) and were kept for 5 days. They were subsequently sputter-coated with gold and

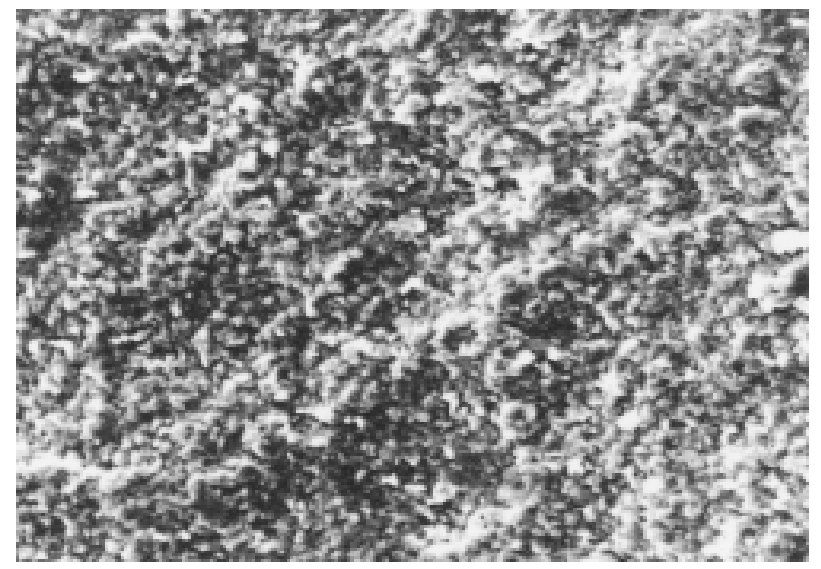

Figure 1. Ceramic stone with round particles and uniform surface without fissures (SEM 500X). submitted to examination in a scanning electron microscope (model Jeol JSM-T330A, Jeol, Tokyo, Japan). Photomicrographs were taken with fine grain Fuji Neopan SS120 film, 3 photomicrographs each, at X100 and X500 magnification.

The findings of the profilometric analysis were compared to those of SEM examination.

\section{RESULTS}

Ceramic Stone $(R a=1.32 \mu \mathrm{m})$. Figure 1 shows a uniform surface without grooves or fissures. The abrasive particles of the stone were found to be small, round and regular, without acute angles. There was a high degree of compaction between the particles that could be attributed to the presence of agglutinate between them.

Newmar Stone (Arkansas type) $(\mathrm{Ra}=2.39 \mu \mathrm{m})$. The stone surface was uniform (Fig. 2), even hough it was possible to see some gaps between the grit particles (arrow). The size of the grains was larger than that of the grains of the ceramic stone and the form of the particle was very irregular. However, there were no pointed angles or high peaks upon the abrasive crystals. In addition, the surface of the particles of this stone appeared burnished.

Arkansas Hu-Friedy Stone ( $R a=2.47 \mu \mathrm{m})$. Although this stone showed some surface irregularities, such as pits or depressions (Fig. 3, arrows), on the whole, there was a high degree of union between the abrasive grains (only minimal gaps were observed between them) that were smaller than the Newmar

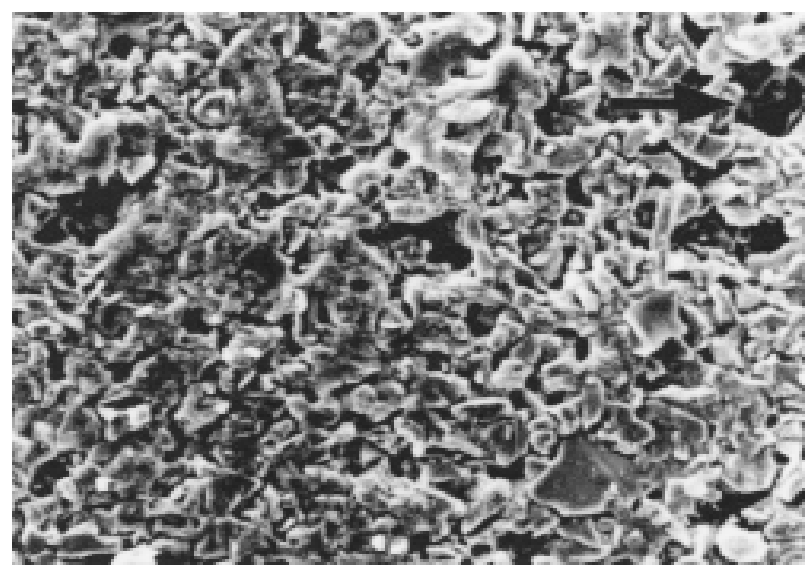

Figure 2. The Newmar stone shows a uniform surface, particles with no pointed angles and gaps (arrow). (SEM 500X). 
stone and slightly larger than the ceramic stone. These particles were round with no peaks or pointed angles and a uniform and regular appearance, even at high magnification (Fig. 4).

Thompson Stone $(R a=3.3 \mu \mathrm{m})$. The size of the grit particles was larger (Fig. 5) than that of the abovementioned three stones (Ceramic, Newmar and Arkansas). In general, the surface of the stone was not completely regular. There were few gaps or fissures between the particles, even though the form of the crystals was irregular with a lack of standardization, being far from the round standard, characteristic of Ceramic and Newmar stones.

$C E$ Stone (Arkansas type) $(R a=4.54 \mu \mathrm{m})$. The characteristics of the $\mathrm{CE}$ stone were similar to Arkansas

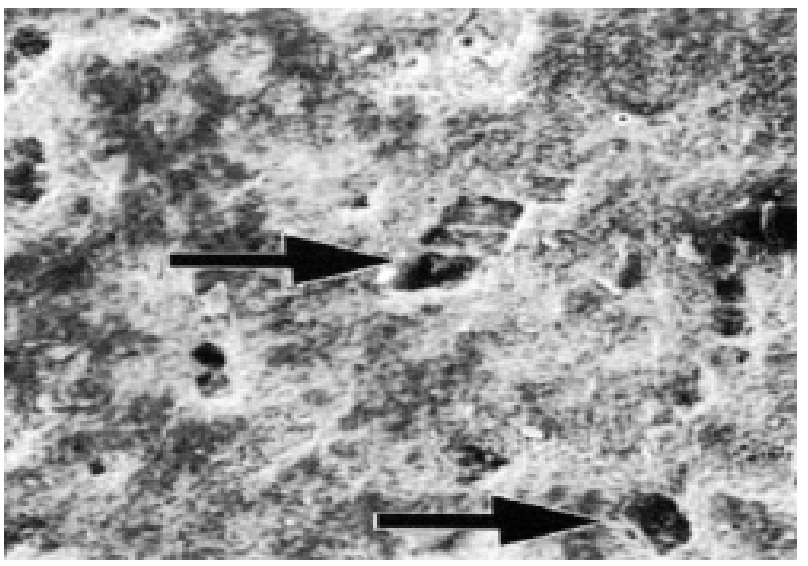

Figure 3. Arkansas Hu-Friedy stone surface with pits (arrows) and round particles with no pointed angles (SEM: 100X).

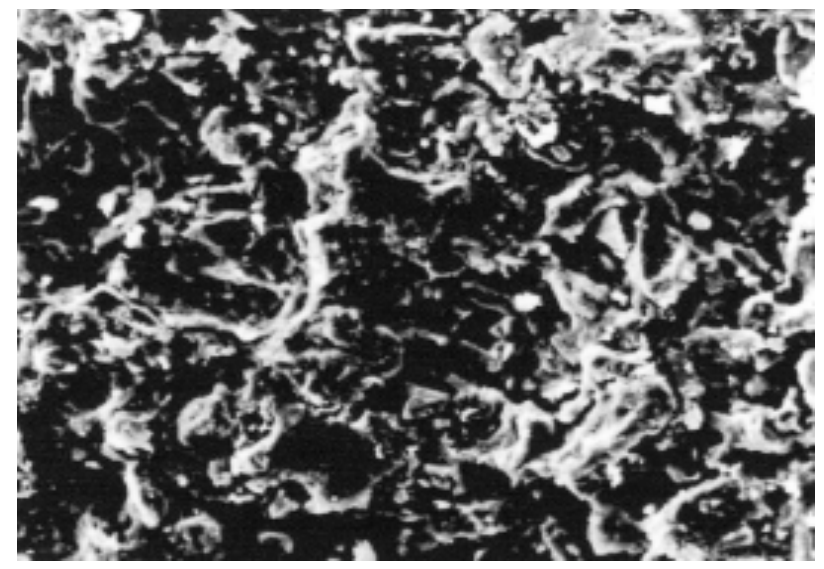

Figure 4. Thompson stone surface was irregular with few gaps between the particles (SEM: 500X).
(Hu Friedy) and Ceramic stones (a very uniform and regular surface with a very small number of gaps between the particles). Their grains were larger than those of the ceramic stone and smaller than those of Thompson stone. The grains of the CE stone were round and had no apparaent pointed angles. There were also depressions and grooves on the entire stone surface alternating with large flat areas (Fig. 6, arrows). This might explain the higher $R a$ value recorded for the CE stone after profilometric analysis.

Carborundum, Norton, Aluminum Oxide and JON Stones ( $R a=4.5 \mu \mathrm{m}$; $R a=5.6 \mu \mathrm{m}$; $R a=6.0 \mu \mathrm{m}$; $R=7.17 \mu \mathrm{m})$. These stones had the roughest grit grain observed. The particles were large and irregular with pointed angles and larger gaps (Figs. 7-10).

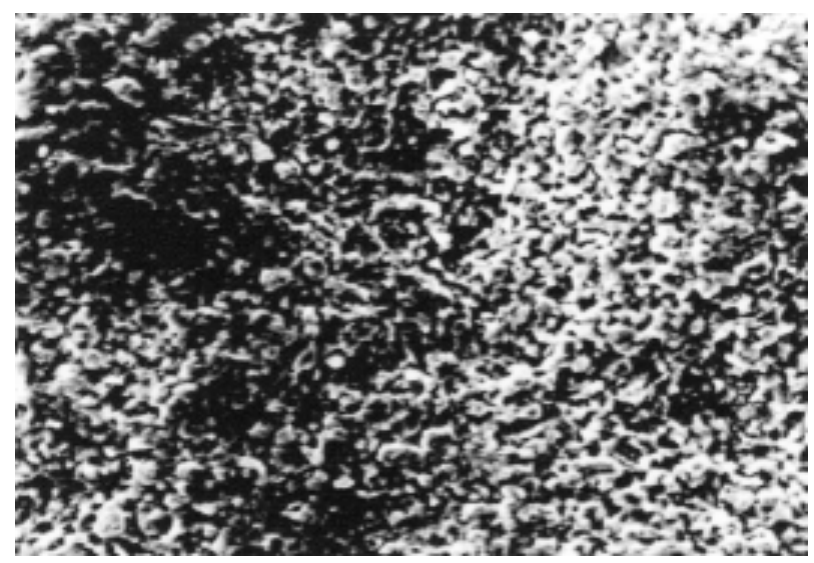

Figure 4. Arkansas Hu-Friedy stone surface at a higher magnifcation (SEM: 500X).

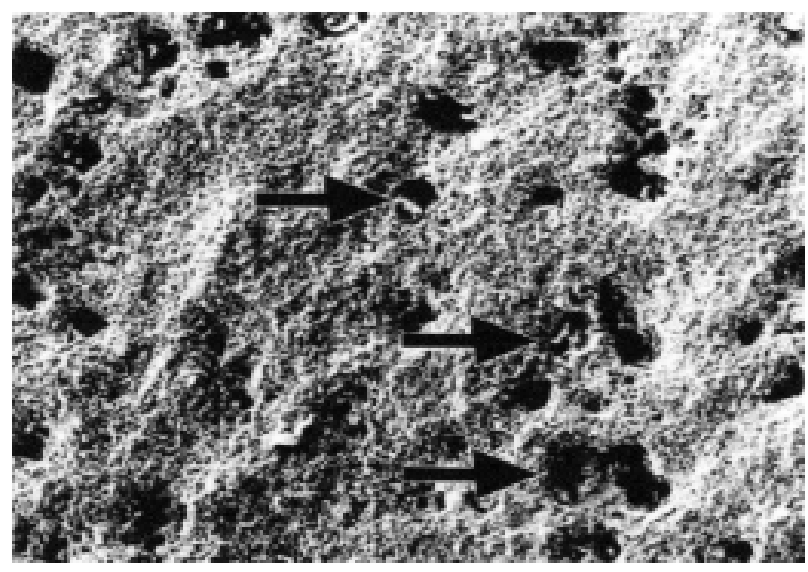

Figure 6. CE stone with several pits (arrows) and rounded particles similar to Arkansas and ceramic stones (SEM: 100X). 


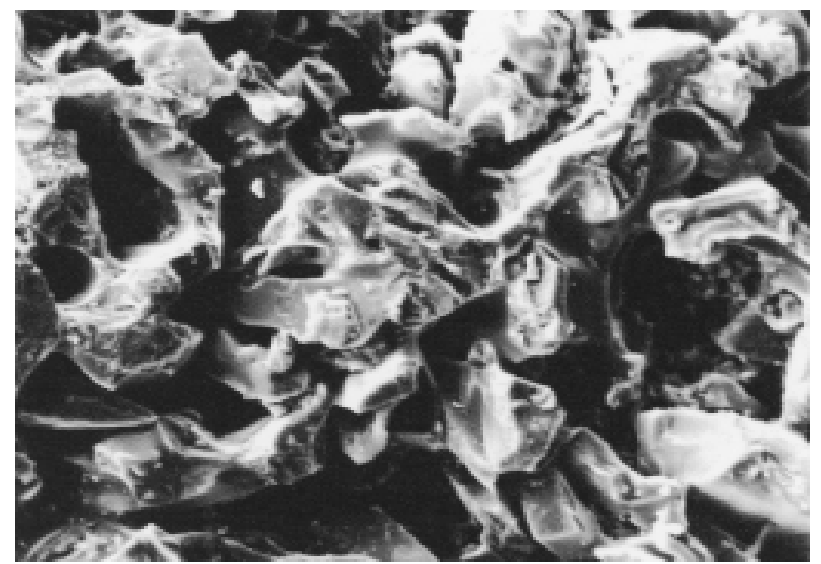

Figure 7. Irregular particles of Carborundum stone with pointed angles and large gaps. (SEM: 500X).

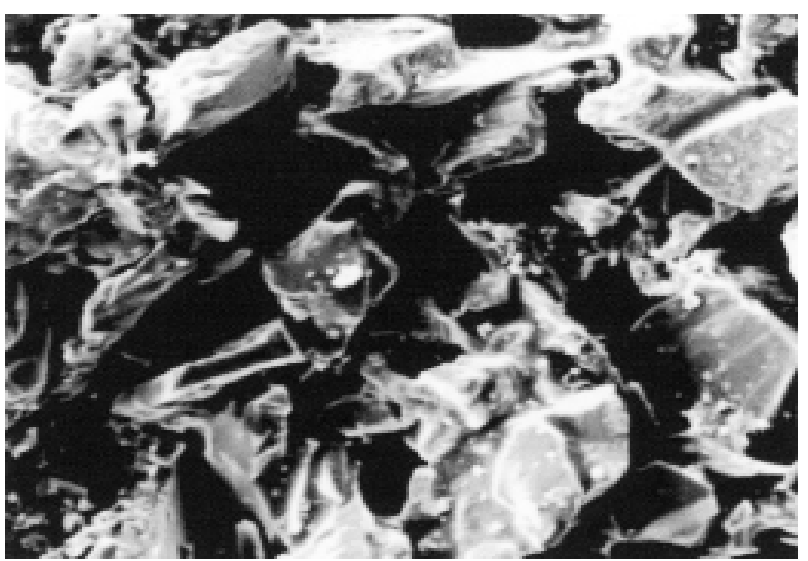

Figure 9. Aluminum Oxide stone surface with large particles with pointed angles, irregular surface and fissures (SEM: 500X).

\section{DISCUSSION}

Scaling and root planning (SRP) is considered the most important phase of periodontal therapy (10). Therefore, it is necessary not only to know instrumentation techniques but also how to maintain periodontal instruments correctly sharpened (7).

It is should be determined which sharpening stones offer more advantages to produce an "ideal" cutting edge. A fine grit stone has small particles, and thus a less abrasive degree, producing a smooth, delicate cutting edge. Coarser stones, with higher abrasive capacity, produce more irregular cutting edges (wire edges) $(11,12)$. This is relevant because the characteristics of the stone surface are directly related to the

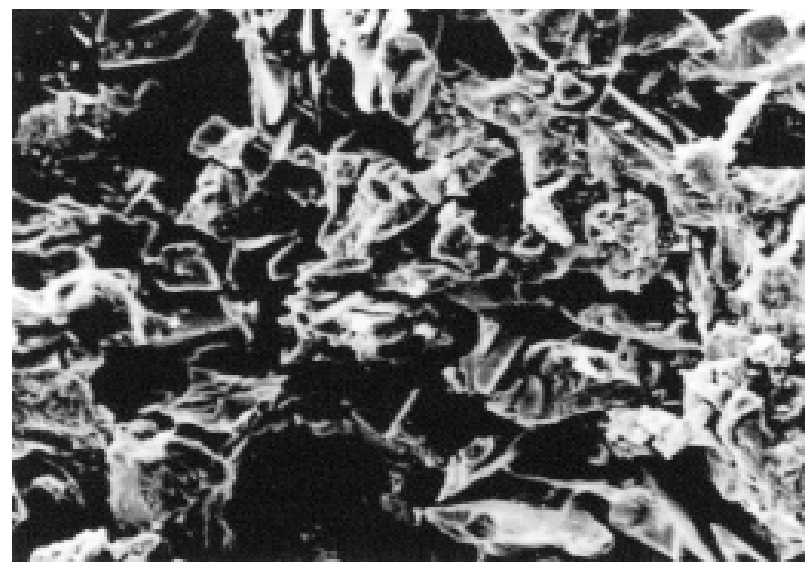

Figure 8. Norton stone presented large abrasive particles with pointed angles, irregular surface and fissures (SEM: 500X).

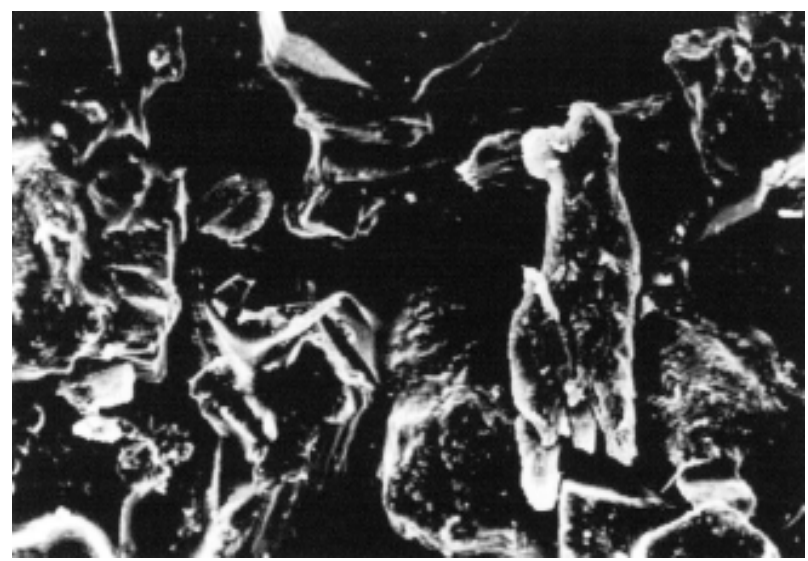

Figure 10. Surface characteristics of JON stone similar to those of Norton and Aluminum Oxide stones (SEM 500X).

quality of the cutting edge and ultimately to root surfaces (8).

Particles of the Ceramic stone (Fig.1) were small and smoother, with a high degree of cohesion between them and with a minimal average roughness value $(R a=1.32)$. This less abrasive stone will abrade the metal slowly with a risk for overheating (13), mainly with dull instruments. In addition, this stone is recommended to maintain instrument sharpness during instrumentation, and not to resharpen partly or totally dull instruments.

Although the Newmar stone presented some gaps on its surface and the particles were more irregular than ceramic and Arkansas (Hu-Friedy) stones (Fig. 2). The low roughness value presented by the Newmar 
stone ( $R a=2.39)$ may be due to a burnished surface because of agglutinating material between the particles that will lead to greater smoothness. This stone has the same indications as ceramic stone.

The Arkansas (Hu-Friedy) stone $(R a=2.47)$ produced the best cutting edge $(8,9,14-17)$ due to the size, round form, uniform disposition and high degree of cohesion between particles (Figs. 3 and 4). This stone had larger grains than the Ceramic stone, abrading the metal easier. It is better indicated to maintain cutting and routine sharpening of partly dull instruments. It is too fine to sharpen totally dull instruments. In this case, it is recommended to begin sharpening with a coarser stone and finish with Arkansas (Hu-Friedy) stone.

Thompson stone had a low roughness value ( $R a$ 3.39), irregular particles and good cohesion degree with some gaps between them (Figs. 5). Because of the size and form of the particles, this stone is more abrasive than the others tested, removing more metal. It is recommended to maintain the cutting edge, and the routine sharpening of partly dull instruments. It could be used with more advantages than the Hu-Friedy stone to sharpen totally dull instruments.

CE $(R a=4.54)$ and Carborundum $(R a=4.5)$ stones had almost identical roughness values, but the photomicrographs showed a visible difference (Figs. 6 and 7). CE stone was very similar to Arkansas (Hu-Friedy) stone (grain size, round form of particles and high cohesion degree). The CE stone presented several grooves dispersed over the surface. The profilometer was not only able to read this sequence of grooves but also registered mixed with the readings of flat areas, resulting in a higher roughness value. If these gaps could be eliminated, the CE stone would be similar to the Arkansas (Hu-Friedy) stone. Therefore, the CE stone has the same indications as the Arkansas stone; however, it is not totally recommended for fine finishing due to the irregularities.

Carborundum, Aluminum Oxide, Norton and JON stones represent the transition between the fine finishing stones (Ceramic, Neumar, Arkansas, Thompson and CE) and the coarser ones, which have large and irregular particles with fissures and peak angles dispersed around them. The capacity of Carborundum stone for removing metal (Fig. 7) is higher, increasing the risk of deformation and overheating of the instrument, producing a more irregular cutting edge (16). Thus, the sharpening technique must be accurate.
The coarser stones can transform a dull instrument into a sharpened one with only a few movements. However, is recommended to not permit an instrument to become completely dull, using fine stones during instrumentation to maintain sharpness, where two or three movements will be sufficient to maintain ideal cutting (18).

The carborundum stone can be indicated for initial grinding of totally dull or very deformed instruments, and a fine stone must be used to eliminate the irregularities produced by the coarser one.

Norton, Aluminum Oxide and JON stones were extremely rough ( $R a=5.6,6.0$ and 7.17, respectively), without a standard of abrasive crystals disposition and their particles were large with many angles around them (Figs. 8-10). They have a high capacity for removal of metal and should not be used as the only way of grinding or for routine sharpening because they leave the highest wire edges and rough cutting edges $(13,15,16)$. They should be used for initial sharpening of dull instruments. Rough stones (Aluminum Oxide, Carborundum, Norton and JON) produced wire edges (unsupported metal projections) and were capable of damaging the root surfaces $(9,15,16,20)$.

Obviously, the different characteristics of stones will not produce equal standards upon root surfaces or cutting edges (8). Thus, it is recommended to use stones with the smallest particle size to obtain the better cutting angle smoothness (9). For that reason, it is preferable to choose stones classified between 280 to 500 grit (19), like Arkansas (Hu-Friedy) stone $(9,15,17,18)$ or similar.

The present study cannot determine which stone produces the best cutting edge, but we point out some characteristics that are important to consider before choosing the sharpening stone. Based on individual stone characteristics and previous reports $(14,20)$, it can be inferred that the final result of the grinding process may be transported to the root surface during instrumentation (8), and thus, future studies are necessary to clarify these concepts.

\section{RESUMO}

Sabe-se que a raspagem e aplainamento (RAR) radicular contribuem na obtenção da saúde periodontal tornando a raiz compatível com os tecidos gengivais. Todo instrumento perde o corte após ser utilizado, tornando-se menos eficaz. Portanto, é necessário mantê-lo corretamente afiado utilizando pedras 
especificas para tal objetivo. Considerando que características do ângulo de corte após a afiação podem ser transportadas para a raiz formando irregularidades semelhantes às da pedra utilizada e que a lisura da raiz está relacionada com a qualidade do ângulo de corte, o objetivo deste estudo foi avaliar sob microscopia eletrônica de varredura e análise em rugosímetro as características de 9 pedras de afiar. As pedras cerâmica e tipo Arkansas (Neumar) mostraram-se muito finas sendo indicadas para a manutenção do corte durante o tratamento; as pedras de Arkansas (Hu-Friedy), Thompson e CE (Tipo Arkansas) apresentaram abrasividade maior com partículas muito regulares e arredondadas, sendo indicadas para a manutenção do corte e afiação rotineira de instrumentos parcialmente sem corte. As pedras de óxido de alumínio, carborundum, Norton e JON (Óxido de Alumínio tipo Arkansas) mostraram-se grossas, com partículas grandes e irregulares, sendo indicadas para a afiação inicial de instrumentos sem corte, requerendo pedras mais finas para o acabamento final.

\section{REFERENCES}

1. Mandel ID, Gaffar A. Calculus revisted: A review. J Clin Periodontol 1986;13:249-257.

2. Gilman RS, Maxey BR. The effect of root detoxification on human gingival fibroblasts. J Periodontol 1986;55:436-440.

3. White DJ. Dental calculus: recent insights into occurrence, formation, prevention, removal and oral health effects of supragingival and subgingival deposits. Eur J Oral Sci 1997;105:508-522.

4. Pattison GL, Pattison AM. Principles of sharpening. In: Periodontal instrumentation. Clinical guidance. Pattison GL, Pattison AM (editors). São Paulo: Editorial Médica Panamericana; 1996. p. 263-283.

5. Tal H, Panno JM, Vaidyanathan TK. Scanning electron microscope evaluation of wear of dental curettes during standardized root planing. J Periodontol 1985;56:532-536.

6. Tal H, Kozlovsky A, Green E, Gabbay M. Scanning electron microscope evaluation of wear of stainless steel and high carbon steel curettes. J Periodontol 1989;60:320-324.

7. Moraes FR, Moraes RG. Sharpening of scalers and gum lancets. In: Periodontics (Série EAP/APCD). São Paulo:Artes
Médicas; 1989. p. 61-92.

8. Biller IR, Karlsson UL. SEM of curet edges. Dent Hyg. 1979;53:549-554.

9. Rossi R, Smukler HA. Scanning electron microscope study comparing the effectiveness of different types of sharpening stones and curets. J Periodontol 1995;66:956-961.

10. Ciancio S. Non-surgical treatment. In: World Workshop in Clinical Periodontics, 1989. Chicago: Princeton. Proceedings of the American Academy of Periodontics; 1989, p. 1516.

11. Pattison AM, Pattison GL, Takei HH. The periodontal instrumentation. In: Clinical Periodontology. Pennsylvania: W.B. Saunders, 1996. chapter 36.

12. Balevi B. Engineering specifics of the periodontal curette cutting edge. J Periodontol 1996;67:374-378.

13. Huang, CC, Tseng CC. Effect of different sharpening stones on periodontal curettes evaluated by scanning electron microscopy. J Formos Med Assoc 1991;90:782-787.

14. Sampaio LM, Sampaio JE. Effect of root surface polishing after manual instrumentation. SEM analysis. Periodontia 1998;7:163-168.

15. Smith BA. Setter MS, Caffesse RG, Bye FL. The effect of sharpening stones upon curet surface roughness. Quintessence Int 1987;18:603-613.

16. Otogoto J. Scaler sharpening. Effect of the cutting edge of scaler and the epoxy resin surface with several types of sharpening stones and strokes. Nippon Shishubyo Gakkai Kaishi 1989;31:583-592.

17. Wehmeyer TE. Chairside instrument sharpening. Quintessence Int 1987;18:615-617.

18. Paquette OE, Levin MP. The sharpening of scaling instruments: II. A preferred technique. J. Periodont 1977;48:169172.

19. Diniz AE, Marcondes FC, Coppini NL. Retification process. In: Material machining technology. São Paulo: MM Editora, 1999. p. 223-241.

20. Andrade Acevedo R, Batista RCW, Sampaio JEC. Assessment of the effect of sharpening with three kinds of sharpening stones using or not lubricant over root surface. Part II. ABO Nac 2002; 10:285-290. 